\title{
Evaluating impact of the education foundation law in management system of the private Indonesian Islamic school
}

\author{
Muhammad Syaifudina, Akhmad Mujahidin' ${ }^{\mathrm{b}}$, Muhammad Fahli Zatrahadi ${ }^{\mathrm{c}}$, Zetri Rahmat ${ }^{\mathrm{d}}$, Habibis \\ Saleh $^{\mathrm{e}}$, and Riki Rahman \\ A, b,c,d,e \\ Universitas Islam Negeri Sultan Syarif Kasim Riau, 28293, Pekanbaru, Riau, \\ Indonesia \\ ${ }^{\mathbf{f}}$ Centre for General Studies and Co-Curricular, Universiti Tun Hussein Onn Malaysia, 86400, Parit Raja, Batu Pahat, Johor, \\ Malaysia
}

Article History: Received: 11 January 2021; Accepted: 27 February 2021; Published online: 5 April 2021

\begin{abstract}
In this paper, we evaluate the impact of the education foundation law in the management system of the private Indonesian Islamic school. Islamic schools or madrasas are the goal of the Muslim community to educate their children where Islamic knowledge and sciences technologies are combined. The private madrasas were initiated, established and organised by the governing boards. Rapidly growing of the private madrasa but lack of management system makes the Indonesian government to stipulate law number 16 of 2001 and law number 28 of 2004. A total of 251 respondents from various foundations among six cities in Indonesia were contacted and interviewed. Instrument analysis was performed using the Rasch model approach through the Winsteps program. We observe that three groups of respondents have the same characteristics of answers. It indicates the tendency of respondents to more agree and practice the mentioned items. The respondents were found to face great difficulties when answering dual positions and authority of the governing boards. We conclude a small impact of the applicable law in the management system of the private madrasa.
\end{abstract}

Keywords: Islamic school, private madrasa, Rasch model, law on education, education management

\section{Introduction}

Islamic education is uniquely different from other types of educational theory and practice primarily because of the all-encompassing influence of the Quran. Islamic education has for centuries, occupied a central role in the transmission of religious knowledge and the shaping of the identity of the global Muslim community [1]. Islamic education in Indonesia falls with most adherents and the world headquarters, and there are thousands of Islamic schools exclusively providing education for students with Islamic-based education [2]. The establishment of a private Islamic school is a form of community participation in fulfilling the national goal under the context of developing the intellectual life of the nation. Since the government has limitations in establishing and managing educational institutions. The state government is only able to establish Islamic public schools. Therefore, the government assist the foundations created by a group of people who have serious concerns for the education of the nation's children, even though the support is only non-material because private Islamic school tend to be materially highly dependent on the founders. The non-material supporting from the Indonesian government can be seen with the issuance of law number 16 of 2001 on foundations [3].

Islamic schools or madrasas are still the goal of the community to educate their children, and this is marked by the high interest of Muslim parents send their children to the private Islamic school [4]. Up to now, madrasas are well-known as traditional and classical religion learning [5]. However, it must be admitted that madrasas have fostered and developed human resources and played a significant role in efforts to enhance intelligence and even improve the dignity of Muslims. Bano reported the madrasas reformation progress in Bangladesh, India and Pakistan [6]. There has been an increase in religious enthusiasm which influence the growing interest among Indonesian Muslim communities to build superior madrasa at various levels of education. It purposes to achieve excellence not only in the field of religious science but also in the field of general science. Therefore, the madrasa was ultimately established to address the challenges of students who have Islamic knowledge and other sciences as well as to practice their knowledge. Thus, students become Indonesian Muslims communities who believe and are only devoted to Allah SWT. Madrasas are no longer seen as institutions for studying scientific religion but also acquire skills, mastery and expertise in the fields of science and technology that are useful for dealing with industrial and post-industrial times [7]. Mohd et al. explored the transformations taken by madrasa, especially in preparing students both in the religious and academic field [8]. Recently, Suyatno et al. [9] indicate that the national education system in Indonesia was affected by the madrasa Quran learning where the eradication of Quran illiteracy program is integrated to all junior high schools.

Attendance of madrasas has increased in the global Muslim population [10]. Asadullah and Chaudhury [11] and Rao and Hossain [12] reported that madrasas are effective in removing gender disparity and in reducing social 
inequalities across the world, respectively. Sirry reported the madrasa's role in the development of civil society discourse in contemporary Indonesia [13]. Asadullah and Chaudhury [11] found that madrasas are associated with attitudes that are still conducive to democracy. Indonesia is a democratic country where two ministries manage the madrasas called the Ministry of Religion in collaboration with the Ministry of Education and Culture in maintaining the quality assurance of education [14]. Several problems can be attributed to intense global competition that makes the private madrasas must continue to be able to develop quality and increase human resources following the times [15], even more, confronted with the fact that this school is an Islamic educational institution that accommodates all Muslims children from all directions. The private school's number has quantitatively increased, numerous new schools have been broad-established everywhere in Indonesia. Private madrasa has experienced especially significant development, as evidenced by the increase in the number of schools building, teachers and students every year.

A number of private madrasas are greater than that of public madrasas. However, most of those attending private madrasas are children whose parents have a lower middle-class economy. This madrasa is managed and supported by many Islamic-based private institutions [2]. Park and Niyozov [16] reported that private madrasa faces a multitude of challenges in preparing students for life in rapidly modernising societies and emerging globalised knowledge economies. With management that is still traditional in private madrasas, impacting on the weakness of the resources of teachers who ultimately teach and meet the quality of teachers then madrasas have designed an alternative effort by borrowing teachers in public madrasas with a part-time work system. The qualified school requires a professional teacher who works according to their fields [17] besides the facilities. Muazza et al. [18] addressed the issue of lack of educational facilities in the private madrasa. Active intervention from the governing boards to the teachers has led to the occurrence of frequent cases improperly firing teachers or put extra pressure on the teachers. This intervention results in education that runs unprofessionally, even though education will affect the overall changes in the future, students who will become national-minded leaders [19]. Besides that, unprofessionalism occurs because of the dual positions between the management of foundations and private madrasas, which makes management ineffective because every decision taken in the direction has been simply influenced by the governing boards.

The above obvious issue has finally demonstrated that people are aware of the need for professional foundations to manage madrasas. Asadullah and Chaudhury [20] mentioned that foundations run a large number of private madrasas around the global Muslim community. Private madrasas are defined as educational institutions that provide Islamic learning as basic subjects [21]. Islamic education foundations cover educational institutions, both formal and informal. Establishment of private madrasas based on the Decree of the Minister of Religion was poured into the Decree of the Director-General of Islamic Community Guidance. Indonesian government stipulates law number 16 of 2001 as a response for professional foundations requirement. This regulation overcomes numerous matters that arise such as, firstly, it is necessary to finish the debate about the legal entity of foundations. Secondly, it is necessary to end the controversy over whether foundations must be social and humanitarian and are allowed to carry out business activities and earn profits. Thirdly, the owners of foundations are individual or people that do not belong to the governing board. The governing board composed of founders, executive and supervisory. Fourthly, the foundations are necessary to be open about the finances and all activities. This is highly required to be regulated by law because madrasas have tended to receive funds sources from donations from people who have excellent financial capabilities, Muslim organisations and other Muslim countries [22]. In addition, Makbuloh [23] mentioned that the madrasa would be regularly accredited in every five years-period to enhance accountability and stakeholders' recognition and quality assurance to produce quality madrasa graduates. This assistance must be in well-managed because it is a mandate from the community.

A fact or incompatible condition was induced by law number 16 of 2001. It raises problems where this regulation specifically provides legal certainty and order in the implementation of education foundations and madrasas under its aegis. Nevertheless, on the other hand, it provokes an intense and emotional reaction from parliament related to foundations; they reasoned that they were not angels. Thus, the aims and objectives of the law on foundations have not been appropriately established, starting from the existence of madrasas that lacked financial support. Yet, it is still not transparent in the flow of funds, the existence of foundation interventions makes it increasingly difficult to apply the law even though it has been perfected by the law number 28 of 2004 . Such current condition is certainly not appropriate if foundations and madrasas comply with the provisions of the applicable law, therefore the current research is especially important to evaluate the impact of the ongoing law referring to the management system of the private madrasas. The measurement is based on the questionnaire and the Rasch measurement model will analyse the raw marks.

\section{Methodology}

A total of 251 respondents from various education foundations among six cities in Riau, Indonesia, were contacted and interviewed. The respondents are the founder, executive and supervisory boards of the education foundations. These boards are called as the governing boards. The questionnaire is divided into two separate instruments. The first questionnaire is consisting of 15 question items using Likert scales consisting of five answer 
choices as tabulated in 1 . The answer choices are strongly disagreed, disagreed, neither agreed nor disagreed, agreed, strongly agreed. The second questionnaire is consisting of 15 question items using Likert scales consisting of five excellence degrees of performance or quality as tabulated in 2. The degrees are very poor, poor, good, very good, excellent. The governing boards initiate, establish, manage and supervise the Islamic junior high school or Madrasa Tsanawiayah (MTS) and the Islamic senior high school or Madrasa Aliyah (MA).

Table 1. Descriptions of 15-question using Likert scales consisting of five answer choices

\begin{tabular}{|c|c|}
\hline No. & Items description \\
\hline $\mathrm{X} 1$ & $\begin{array}{l}\text { The governing boards should not get a salary, wage or } \\
\text { honorarium }\end{array}$ \\
\hline $\mathrm{X} 2$ & $\begin{array}{l}\text { The governing boards must provide an opportunity for a teacher } \\
\text { to be actively involved in teacher training and workshop to } \\
\text { increase teacher professionalism development }\end{array}$ \\
\hline X3 & $\begin{array}{l}\text { The governing boards have full authority to pay the teacher and } \\
\text { academic staff }\end{array}$ \\
\hline $\mathrm{X} 4$ & $\begin{array}{l}\text { The governing boards have provisions regarding the } \\
\text { composition and procedure for appointment dismissal, and } \\
\text { replacement of madrasa management regulated in the Articles of } \\
\text { Association }\end{array}$ \\
\hline X5 & $\begin{array}{l}\text { The foundation must have supervisory boards to maintain } \\
\text { financial stability }\end{array}$ \\
\hline X6 & I like to handle whatever comes my way \\
\hline $\mathrm{X} 7$ & The executive board is allowed to be the supervisory board \\
\hline $\mathrm{X} 8$ & $\begin{array}{l}\text { The founder boards must avoid the possibility of overlapping } \\
\text { authority, duties, and responsibilities among the executive and } \\
\text { supervisory boards that can harm the interests of the foundation or } \\
\text { other parties }\end{array}$ \\
\hline X9 & $\begin{array}{l}\text { The governing board cannot be part of the madrasa } \\
\text { management }\end{array}$ \\
\hline $\mathrm{X} 10$ & $\begin{array}{l}\text { The governing boards are prohibited from concurrently serving } \\
\text { as director or commissioners foundation business }\end{array}$ \\
\hline $\mathrm{X} 11$ & $\begin{array}{l}\text { The governing boards must be open-minded with financial } \\
\text { statements }\end{array}$ \\
\hline $\mathrm{X} 12$ & $\begin{array}{l}\text { The governing boards must prepare an annual report and } \\
\text { display it in the announcements board }\end{array}$ \\
\hline $\mathrm{X} 13$ & $\begin{array}{l}\text { The executive boards must prepare financial statements } \\
\text { consisting balance sheet, income statements, cash flow statements } \\
\text { and summary reports }\end{array}$ \\
\hline $\mathrm{X} 14$ & The supervisory boards may not agree to sign the annual report \\
\hline $\mathrm{X} 15$ & $\begin{array}{l}\text { The founder boards must extend or terminate the executive and } \\
\text { supervisory boards during the annual meeting }\end{array}$ \\
\hline
\end{tabular}

The instrument analysis was performed using the Rasch model approach through the Winsteps program. In the Rasch model approach, besides considering to items also pay close attention to aspects of respondents and calculate the magnitude of the correlation. The advantages of Rasch modelling compared to other methods, especially classical test theory, are the ability to predict missing data based on individual response patterns. These advantages make the statistical analysis results of the Rasch model more accurate in the research conducted, and more importantly, the Rasch model can produce standard error measurement values for the instruments used and can improve the accuracy of calculations. The Rasch measurement model involves the difficulty of the questions 
and the ability of the founder, executive and supervisory boards to verify the questions [24]. Rash analysis can be used to transform the response scales into linear interval scales, performed verification and validation, especially when construct invariance across different respondent is essential. This analysis can analyse the psychometric properties of a scale and identify overlapping response categories that can be joined.

Table 2. Descriptions of 15-question using Likert scales consisting of five degree of excellence

\begin{tabular}{|c|c|}
\hline No. & Items description \\
\hline Y1 & I read carefully and understand the law number 28 of 2004 \\
\hline Y2 & I apply every aspect of the law in my foundation \\
\hline Y3 & $\begin{array}{l}\text { I conduct an annual meeting to evaluate the assets, the rights } \\
\text { and obligations }\end{array}$ \\
\hline Y4 & $\begin{array}{l}\text { The madrasa director in my foundation is a appointed by the } \\
\text { governing boards for five years and may be reappointed for the } \\
\text { next five years }\end{array}$ \\
\hline Y5 & $\begin{array}{l}\text { The wealth and assets of my foundation come 100\% from the } \\
\text { religious endowment }\end{array}$ \\
\hline Y6 & My foundation has the standard Articles of Association \\
\hline Y7 & $\begin{array}{l}\text { I understand that amendments of the Articles of Association } \\
\text { cannot be made when the foundation is declared bankrupt }\end{array}$ \\
\hline Y8 & $\begin{array}{l}\text { The governing boards in my foundation were composed by at } \\
\text { least: }\end{array}$ \\
\hline Y9 & $\begin{array}{l}\text { My foundation receives financial support from the government } \\
\text { regularly }\end{array}$ \\
\hline Y10 & I do not intervene the madrasa director \\
\hline Y11 & $\begin{array}{l}\text { The madrasa director is informed about the flow of funds } \\
\text { received by the foundation }\end{array}$ \\
\hline Y12 & $\begin{array}{l}\text { Every teacher carries out their duties and loyal to the madrasa } \\
\text { director and the governing boards }\end{array}$ \\
\hline Y13 & $\begin{array}{l}\text { The existence of the law has a direct impact on madrasa } \\
\text { management }\end{array}$ \\
\hline Y14 & $\begin{array}{l}\text { The madrasa director has the independence to generate income } \\
\text { without relying on the governing boards }\end{array}$ \\
\hline Y15 & $\begin{array}{l}\text { My foundation stipulates madrasa regulations on quality } \\
\text { assurance according the law number } 28 \text { of } 2004\end{array}$ \\
\hline
\end{tabular}

The present study has adopted varied approaches to the review, such as through Ex post facto design. The researchers attempt to take the effects of the dependent variable and retrospectively examine it to determine the cause, relationship, association, or meaning. The researchers cannot manipulate variables and only describe what happens to the independent variables and look for information about the causal relationships of the events. After the data were collected from interviewing the governing boards, then data analysis is performed. In order to perform tests of the statistical significance, the ANOVA model is considered. The response variable in ANOVA or may called as the dependent variable is quantitative as in regression. However, the independent variable or the factor is qualitative. The ANOVA analysis is used to determine a relationship between the factor and response variables. 


\section{Data Analysis and Discussion}

Table 3 shows the summary of Rasch statistics for 251 respondent who answer 15 questions from the first questionnaire. The person measure average is 1.87 , which indicated the value of the respondent. Values greater than 0.0 indicate the tendency of respondents to more agree.

Table 3. Person summary statistics of the first instruments

\begin{tabular}{ccccc}
\hline & $\begin{array}{c}\text { Logit } \\
\text { measure }\end{array}$ & $\begin{array}{c}\text { Model } \\
\text { error }\end{array}$ & $\begin{array}{c}\text { Outfit Mean } \\
\text { square }\end{array}$ & $\begin{array}{c}\text { Z- } \\
\text { Std }\end{array}$ \\
\hline Mean & 1.87 & 0.45 & 0.99 & - \\
\hline S.D & 1.23 & 0.11 & 0.49 & 1.3 \\
\hline Max & 4.96 & 1.03 & 3.03 & 3.4 \\
\hline Min & -0.68 & 0.35 & 0.13 & - \\
\hline $\begin{array}{l}\text { S.E of Person } \\
\text { Person reliability }\end{array}$ & 0.82 & & & \\
\hline $\begin{array}{c}\text { Probach Alpha } \\
\text { mean separation }\end{array}$ & 0.08 & & & \\
\hline KR-20) & 0.85 & & & \\
\hline
\end{tabular}

Cronbach's Alpha in Table 3 is 0.85 , which measures reliability is the interaction between person and item as a whole. The Cronbach's alpha coefficient must greater than 0.8 [25]. Person reliability value of 0.82 indicates that the consistency of respondents' answers and the quality of items in the category good. The person distribution is sufficient enough to reveal the different levels of person proficiency. The maximum proficiency level is at 4.96 logit and the lowest proficiency level is at -0.68 logit, which gives a spread of 5.64 logit on the scaling with S.E of Person mean is 0.08. Mean square outfit (MNSQ) for the person table the average values is 0.99 , where the ideal value is 1.00 . MNSQ value has to be positive and when the MNSQ larger than unity reveal that the data had great noise, and the MNSQ approaches zero reveal it is too consistent. The expected values are in interval 0.7 to 1.4 [26]. Any individual item with a value greater than 2.0 will be deleted from the current work. For Z-Std value of the person table is -0.1 where the ideal value is 0.0 . The index value of separation can determine the grouping of persons and items. The greater the separation, the higher the instrument quality. Person separation index is 2.11, which satisfied the requirement above 2.0 [25]. Calculated $\mathrm{H}$-value is 3.14 where $\mathrm{H}=[(4 \times 2.11)+1] / 3$. Here $\mathrm{H}$ is strata referring to the actual value of individual level. This value is rounded to 3 , which means that three groups of respondents have the same tendency of answers.

Table 4. Measure order of the item statistics from 15-questions in the first questionnaire

\begin{tabular}{ccccc}
\hline No. & $\begin{array}{c}\text { Item } \\
\text { number }\end{array}$ & $\begin{array}{c}\text { Item } \\
\text { measure }\end{array}$ & $\begin{array}{c}\text { Outfit } \\
\text { Square }\end{array}$ & Z-Std \\
\hline 1 & $\mathrm{X} 9$ & 0.60 & 0.75 & -3.0 \\
\hline 2 & $\mathrm{X} 4$ & 0.53 & 0.76 & -2.8 \\
\hline 3 & $\mathrm{X} 14$ & 0.43 & 1.10 & 1.1 \\
\hline 4 & $\mathrm{X} 8$ & 0.37 & 1.46 & 4.4 \\
\hline 5 & $\mathrm{X} 12$ & 0.35 & 1.50 & 4.8 \\
\hline 6 & $\mathrm{X} 1$ & 0.26 & 1.21 & 2.2 \\
\hline 7 & $\mathrm{X} 13$ & 0.22 & 0.82 & -2.0 \\
\hline 8 & $\mathrm{X} 6$ & 0.14 & 0.82 & -1.9 \\
\hline
\end{tabular}




\begin{tabular}{lllll}
\hline 9 & $\mathrm{X} 15$ & -0.11 & 1.04 & 0.4 \\
\hline 10 & $\mathrm{X} 10$ & -0.23 & 0.70 & -3.3 \\
\hline 11 & $\mathrm{X} 11$ & -0.37 & 0.83 & -1.7 \\
\hline 12 & $\mathrm{X} 2$ & -0.41 & 0.90 & -0.9 \\
\hline 13 & $\mathrm{X} 7$ & -0.50 & 0.80 & -2.0 \\
\hline 14 & $\mathrm{X} 3$ & -0.53 & 1.21 & 1.8 \\
\hline 15 & $\mathrm{X} 5$ & -0.74 & 0.91 & -0.8 \\
\hline Mean & & 0.0 & 0.99 & -0.3 \\
\hline S.D. & & 0.42 & 0.25 & 2.5
\end{tabular}

Table 4 shows the measurement of the 15-questions from the first questionnaire. Measurement of the value of logits to be able to determine which items are the most difficult to accept and agree with respondents. The most challenging question is $\mathrm{X} 9$-item located at the top of the item distribution, while the most comfortable question is X5item located at the bottom of the item distribution. The X5-item presents no difficulties from the respondent to answer the question about maintaining financial stability. The respondents face great difficulties when answering double positions of the governing board as symbolized by X9. Ranking X9 follows by X4, not moving from the governing board issue. Here the respondent maybe not agreed to the governing board's authority in the composition and procedure for appointment dismissal and replacement of the madrasa manager. The MNSQ and the Z-Std are closer to their expected values 1.0 and 0.0 , respectively. This confirms satisfactory fit to the model.

Table 5. Standardized residual variance statistics of the first instrument

\begin{tabular}{ll}
\hline Raw variance types & Eigenvalue percentage \\
\hline $\begin{array}{c}\text { Total raw variance in } \\
\text { observation }\end{array}$ & $100.0 \%$ \\
\hline $\begin{array}{l}\text { Raw variance explained by } \\
\text { measures }\end{array}$ & $34.2 \%$ \\
\hline $\begin{array}{l}\text { Raw variance explained by } \\
\text { persons }\end{array}$ \\
\hline $\begin{array}{l}\text { Raw variance explained by } \\
\text { items }\end{array}$ \\
\hline $\begin{array}{l}\text { Raw unexplained variance } \\
\text { (total) }\end{array}$
\end{tabular}

Table 5 shows the standardised residual variance statistics of the first instrument. Unidimensionality check is a requisite to the summation of any set of items. Unidimensionality instrument means a critical measure to evaluate whether the instrument can measure what should be measured. Raw variance explained by measures is $34.2 \%$, the emerging result shows that minimum unidimensionality requirements of $15 \%$ can be fulfilled. This instrument meets the criteria for measuring what should be measured. The raw variance smaller than $15 \%$, reveals that the pattern of responses from the item is not consistent and the whole responses do not conform to the survey intentions.

Table 6. Person summary statistics of the second instruments

\begin{tabular}{ccccc}
\hline & $\begin{array}{c}\text { Logit } \\
\text { measure }\end{array}$ & $\begin{array}{c}\text { Model } \\
\text { error }\end{array}$ & $\begin{array}{c}\text { Outfit Mean } \\
\text { square }\end{array}$ & $\begin{array}{c}\text { Z- } \\
\text { Std }\end{array}$ \\
\hline Mean & 2.29 & 0.5 & 0.99 & - $^{-}$ \\
\hline S.D & 1.17 & 0.09 & 0.41 & 1.0 \\
\hline Max & 5.09 & 1.03 & 2.91 & 3.4 \\
\hline
\end{tabular}




$\begin{array}{lllll}\text { Min } & -1.09 & 0.37 & 0.31 & 2.4^{-}\end{array}$

\begin{tabular}{|c|c|}
\hline Person reliability & 0.80 \\
\hline Person separation & 1.99 \\
\hline $\begin{array}{l}\text { S.E of Person } \\
\text { mean }\end{array}$ & 0.1 \\
\hline $\begin{array}{l}\text { Crobach } \\
(\text { KR-20) }\end{array}$ & 0.85 \\
\hline
\end{tabular}

Table 6 shows the summary of Rasch statistics for 251 respondent who answer 15 questions from the second questionnaire. The conducted results show the person measure is 2.29 , which indicated the value of the respondent. Values greater than 0.0 indicate the tendency of respondents to more agree. Cronbach's Alpha value of 0.85 , which measures reliability is the interaction between person and item as a whole. Person reliability value of 0.80 and item reliability of 0.82 indicate that the consistency of respondents' answers and the quality of items in the category Good. MNSQ for the person table the average values is 0.99 . Z-Std of the average value of the person table is -0.1 . The value of separation can determine the grouping of persons and items. The greater the separation, the higher the instrument quality. The value of person separation is 1.99 , then $\mathrm{H}$-value is 2.98 . Such formulated number is rounded to 3 , which means that three groups of respondents have the same tendency of answers.

Table 7. Measure order of the item statistics from 15-questions in the second questionnaire

\begin{tabular}{ccccc}
\hline No. & $\begin{array}{c}\text { Item } \\
\text { number }\end{array}$ & $\begin{array}{c}\text { Item } \\
\text { measure }\end{array}$ & $\begin{array}{c}\text { Outfit } \\
\text { Square }\end{array}$ & Z-Std \\
\hline 1 & Y4 & 0.56 & 0.95 & -0.5 \\
\hline 2 & Y6 & 0.35 & 0.81 & -2.4 \\
\hline 3 & Y10 & 0.25 & 0.96 & -0.4 \\
\hline 4 & Y15 & 0.18 & 1.02 & 0.2 \\
\hline 5 & Y9 & 0.09 & 0.87 & -1.6 \\
\hline 6 & Y7 & 0.06 & 1.12 & 1.4 \\
\hline 7 & Y8 & 0.05 & 1.33 & 3.6 \\
\hline 8 & Y12 & 0.04 & 1.06 & 0.8 \\
\hline 9 & Y14 & -0.02 & 1.16 & 1.8 \\
\hline 10 & Y2 & -0.06 & 0.88 & -1.5 \\
\hline 11 & Y11 & -0.10 & 0.83 & -2.0 \\
\hline 12 & Y5 & -0.22 & 1.06 & 0.7 \\
\hline 13 & Y13 & -0.22 & 0.88 & -1.4 \\
\hline 14 & Y3 & -0.28 & 0.94 & -0.7 \\
\hline 15 & Y1 & -0.68 & 0.93 & -0.6 \\
\hline Mean & & 0.0 & 0.99 & -0.2 \\
\hline S.D. & & 0.28 & 0.14 & 1.6 \\
\hline
\end{tabular}

Table 7 shows the measurement of the 15 questions from the second questionnaire. Measurement of the value of logit to be able to determine which items are the most difficult to accept and agree with respondents. The most challenging question is Y4item located at the top of the item distribution, while the most straightforward question is Y1-item located at the bottom of the item distribution. The Y1-item presents no difficulties from the respondent 
to answer the question about knowing the law number 28 of 2004. The respondents face great difficulties when answering appointments of the madrasa director. Ranking Y4 follows by Y6, whether the foundation has or has not the standard Articles of Association. Here the respondent may not fully understand what the standard Articles of Association based on the Indonesian government policy is. The MNSQ and the Z-Std are closer to their expected values 1.0 and 0.0 , respectively, for the respondents and the questions. This confirms satisfactory fit to the model.

Table 8. Standardized residual variance statistics of the second instrument

\begin{tabular}{|c|c|}
\hline Raw variance types & Eigenvalue percentage \\
\hline $\begin{array}{ccc}\text { Total raw } & \text { variance } & \text { in } \\
\text { observation }\end{array}$ & $100.0 \%$ \\
\hline $\begin{array}{l}\text { Raw variance explained by } \\
\text { measures }\end{array}$ & $33.7 \%$ \\
\hline $\begin{array}{l}\text { Raw variance explained by } \\
\text { persons }\end{array}$ & $18.5 \%$ \\
\hline $\begin{array}{l}\text { Raw variance explained by } \\
\text { items }\end{array}$ & $15.1 \%$ \\
\hline $\begin{array}{l}\text { Raw unexplained variance } \\
\text { (total) }\end{array}$ & $66.3 \%$ \\
\hline
\end{tabular}

Tabel 8 shows standardised residual variance statistics the second instrument. Raw variance explained by items $15.1 \%$, this indicates that the minimum unidimensionality requirement of $15 \%$ can be fulfilled. These instruments meet the criteria for measuring what should be measured. The raw variance has to greater than $15 \%$ to prove the stability in the answering structure. In addition, the unidimensional scaling was based on the equivalent measurement model and that it fit the Rasch model. It enables the Liker scores to be compared across instrument employing cocalibration and item indicators.

Table 9. Pearson correlation coefficient

\begin{tabular}{|c|c|c|}
\hline Correlation description & $\mathrm{X}$-items & Y-items \\
\hline Response to the law number 28 of 2004 & 1 & -0.004 \\
\hline $\begin{array}{l}\text { Implementation } \\
\text { management }\end{array}$ & -0.004 & 1 \\
\hline
\end{tabular}

Linear correlation between $\mathrm{X}$-items and Y-items is measured using the Pearson correlation coefficient as tabulated in Table 9. It notes that the correlation is significant at the 0.01 level (2-tailed). The results of the correlation calculation in this table provide a direct correlation value of -0.004 . This correlation indicates that there is no significant relationship between the implementation of law number 28 of 2004 with madrasa management based on the well-established criteria. The correlation value of -0.004 is not in the range from 0.0 to 0.199 . The calculated coefficient is negative and we conclude that law 28 of 2004 has no impact on the management system of the private madrasas.

Table 10. Statistics summary applied to the test hypotheses

\begin{tabular}{lccccc}
\hline Description & B & $\begin{array}{c}\text { Std. } \\
\text { error }\end{array}$ & Beta & $\begin{array}{c}\text { Complement } \\
\text { value }\end{array}$ & $\begin{array}{c}\text { Significance } \\
\text { value }\end{array}$ \\
\hline Constant & 67.063 & 4.305 & & 15.579 & 0.0 \\
\hline $\mathrm{Y}$ & -0.041 & 0.065 & - & -0.622 & 0.534 \\
& & & 0.039 & & \\
\hline
\end{tabular}

R square $\quad 0.002$

Table 10 shows the statistics summary applied to the test hypotheses. Based on the results obtained in this line of research, it is therefore argued that the significance value of 0.534 is higher than the probability of 0.05 , and it is therefore concluded that there is a small effect of the implementation of foundation law on the quality of madrasa education management. This is due to the weak relationship between the response to law number 28 of 2004 and implementation to madrasa management. The weaker response to the law, the weaker implementation 
to the madrasa management will be. From these formulated data, it is known that R square is 0.002 . Finally, evaluating the impact given to the madrasa management was very small at $0.2 \%$, while $99.8 \%$ was influenced by other things not examined in this study. On the other hand, high expectation of the governing boards to the government is required to conduct socialization.

There are some limitations in the present study. First, with the obtained data, we could not explore how many indicators should be used in the response scores. In addition, were all the governing boards so that the obtained results can not be generalised to madrasa director or teacher samples. Finally, we use our measuring, including objective measures to test the validity of the instruments or indicators. However, this was not considered a severe limitation since the Cronbach's Alpha values, person reliability values, item reliability value, MNSQ numbers, Z-Std scores and unidimensionality checked satisfied the ideal conditions.

We have discussed the complexity of attributing changes in madrasa management outcomes to changes by the law application. Evaluating the impact of the ongoing law are conducted ex-post-facto study design. This work explains the need for indicators to measure relevant outcomes of concern and instruments to support inferences about the extent to which law under evaluation has caused any change in the measured outcomes. Indicators depend on the specific problems of concern to the Indonesian government. However, the best indicators will generally be those that measure the ultimate problem the law was intended to solve. Measuring indicators for evaluating the law and reporting several indicators that can be utilized to measure outcomes, which able to inform the Legislative Assembly of a revised framework.

\section{Conclusions}

In this study, a scale for measuring the impact of the law number 16 of 2001 and law number 28 of 2004 was developed, verified and validated by applying the Rasch model. The scale is a useful instrument for measuring impact on ongoing law referring to the management system of the foundation education in managing the private Indonesian Islamic school or madrasa. ANOVA model is considered for performing tests of the statistical significance. Value of the Cronbach's Alpha, person reliability, item reliability, MNSQ, Z-Std and unidimensionality checked are satisfied the ideal conditions. We observe that three groups of respondents have the same characteristics of answers. It indicates the tendency of respondents to more agree and practice the mentioned items. The respondents were found to face great difficulties when answering dual positions and authority of the governing board. We found that the impact on the applicable law is minimal at $0.2 \%$. To know how satisfactory law works in practice, the Indonesian government need to give more substantial resources and more considerable attention to choose reliable indicators and appropriate research instruments needed to perform more ex-post evaluation. Foundations and madrasas of strictly applied ex-post assessment will help ensure more informed the Legislative Assembly in the succeeding law.

\section{References}

1. Ho W Y 2014 Mod. Asian Stu. 48 399-432

2. Asadullah M N and Maliki M 2018 Int.J. of Edu. Dev. 62 96-111

3. Syaifudin M 2017 Al-Fikra 5 70-89

4. Asadullah M N, Chakrabarti R and Chaudhury N 2015 Bull. of Eco. Res. 67 186-207

5. Tan, C 2015 J. Ilm. Peurad. 3 417-430

6. Bano M 2014 Modern Asian Stu. 48 911-939

7. Mundiri A and Zahra I 2017 J. Pend. Islam Ind. 2 21-35

8. Mohd N M R, Senin N, Mohd K H K and Abdul H A 2017 J. for Multic. Edu. 11 238-249

9. Suyatno S, Jumintono J, Pambudi D I, Mardati A and Wantini W 2019 Inter. J. of Instruct. 12 $607-$ 624

10. Krafft C, Elbadawy A and Sieverding M 2019 Int. J. of Edu. Dev. 71 102-104

11. Asadullah M N and Chaudhury N 2010 World Dev. 38 205-217

12. Rao N and Hossain M I 2011 Int. J. of Edu. Dev. 31 623-633

13. Sirry M 2010 The Muslim World 100 60-77

14. Harun C, Khairuddin K and Niswanto N 2018 Proc. of the First Int. Grad. Conf. (Aceh: European Alliance for Innovation)

15. Kim C M, Kim M K, Lee C, Spector J M and DeMeester K 2013 Teaching and Teacher Edu. 29 76-85

16. Park J and Niyozov S 2008 Asia Pac. J. of Edu. 28 323-351

17. Guskey T R 2002 Teaching and Teacher Edu 8 381-391

18. Muazza M, Mukminin A, Habibi A, Hidayat M and Abidin A 2018 Islamic Quart. 62 507-536

19. Korthagen F A J 2004 Teaching and Teacher Edu. 20 77-97

20. Asadullah M N and Chaudhury N 2013 The J. of Dev. Stu. 49 223-237

21. Pohl F 2006 Comp. Edu. Rev. 50 389-409

22. Mokhtar I A 2010 J. of Muslim Min. Aff. 30 111-125

23. Makbuloh D 2017 Adv. Sci. Lett. 23 948-952 
24. Rasch G 1980 Probabilistic Models for Some Intelligence and Attainment Tests (Copenhagen, Denmark: Danish Institute for Educational Research)

25. Fisher, W. (1992). Reliability, separation, strata statistics. Rasch measurement transaction, 6, 238

26. Smith A B, Rush R, Fallowfield L J V G and Sharpe M 2008 BMC Med. Resch. Meth. 833 